\title{
Chiefs dominate indians at an annual science smorgasbord
}

\section{Chicago}

THE gamble by the American Association for the Advancement of Science (AAAS) to hold this year's annual meeting here in mid-winter appears to have succeeded; there has been no snow during the fiveday meeting, while the biting wind off Lake Michigan has not been much worse than it can be in summer. The result is that there were roughly 3,400 members (a lot better than last year) at the smorgasbord of hard science made popular (or at least intelligible) and of public policy made technical. There were sessions on everything from particle physics and arms control to the state of Lake Michigan (whose level has risen $1.5 \mathrm{~m}$ in five years) and the chance to see night baseball at Wrigley Field, the home of the Chicago Cubs.

The most constant crowd was that at the neuroscience symposium organized by Dr Daniel L. Alkon of the Marine Biological Station at Woods Hole, a kind of currentawareness course equally suitable for outsiders and for those working in the field. And the highlight of that was the astonishing cine-film-footage from Thomas $\mathrm{S}$. Reese (also from Woods Hole) of the movement of mitochondria and packets of neurotransmitter substances along the cytoskeletal microtubules with which the neuronal cytoplasm seems to be packed. It is not so much the measured speed (up to $40 \mathrm{~cm}$ a day) as the manner of travel that had Reese's audience spellbound. Mitochondria seem to wriggle their way along the microtubles like loose-fitting railway wagons along a track, sometimes half a dozen or more in line, occasionally changing track.

Other crowds were not so big (AAAS's worry) and seemed sometimes to be outnumbered by the speakers; the effect can be anticlimactic if a panel wishes to pose grand questions best suited to crowded halls, as did the speakers in the five days of talks about the US space programme after Challenger.

The government view is that the manned space station is the "cornerstone" of the next decade's programme for NASA (National Aeronautics and Space Administration), but academic researchers dissent. Ricardo Giacconi, developer of the Einstein X-ray satellite and now director of the NASA-supported Space Telescope Science Institute, flatly told a panel of government officials that there is "very little" support for the space station in the academic community. Giacconi's view is that NASA's commitment to people in space has caused the costs of scientific projects to skyrocket. While thrilling a larger audience with a vision of what trans-spectral astronomy beyond the atmosphere can accomplish, he complained that servicing the Hubble Space Telescope from the space shuttle will cost almost as much as building a second telescope.

Among the grand questions, that of how cold it will be after a nuclear war remains alive, even though $\mathrm{S}$. Fred Singer, a physicist at George Mason University, Virginia, heaped criticism on models predicting severe cold for their failure to take account of the properties in the infrared of the smoke and ice-clouds that would form after a nuclear exchange. He argued that there would be a greenhouse effect, as a result of water vapour carried into the stratosphere coupled with smoke lower in the atmosphere, huge enough to turn nuclear winter into nuclear summer.

But Stephen Schneider, of the National Center for Atmospheric Research in Boulder, Colorado, accused Singer of raising an "infrared herring". Schneider says Singer's physical issues do not change predictions that temperatures would drop after a nuclear exchange. Schneider says a low smoke cloud's infrared properties would not be significant, although the ice issue may have some relevance. But, in any case, said Schneider, even a relatively small drop in temperature could be disastrous if it produced a frost during the growing season. Schneider believes a more serious issue yet to be given the attention it deserves is the effect of fog on post-war temperature.

Pre-war as well as post-war problems were examined if not solved at AAAS. On arms control, Roger Fisher, a professor at the Harvard Law School, said at one point during five days of discussion of security issues that US negotiators may be good at presenting positions, but are less good at plotting strategy for making progress. One way to succeed is to describe new positions without commitment. In the same vein at a different meeting, Professor Thomas Schnelling, also of Harvard, had asked for a "moratorium on arms control negotiations" not only because of the damage they can do but because they divert attention from other beneficial courses of action.

Of necessity, there were not many jokes in these sessions, and even Academician R.Z. Sagdeev's joke was a black one. Seeking a simple model of the doctrine of mutually assured destruction, he told of the Russian couple who, when asked at their silver wedding how their marriage could have survived all the tribulations of married life, replied that they had filled their basement with dynamite, and that each had had a button.

John Maddox \& Joseph Palca

\section{Czechs agree with Poles over water pollution}

\section{London}

THE Czechoslovak Minister for Forestry and Water Management, Franktisek Kalina, last week officially "deplored and apologized for" the effects of the oil spillage at the Kunice cement works last November, which polluted the Oder and caused considerable damage in the Polish province of Katowice. After a two-day meeting in Krakow with the Polish Environment Minister, Stefan Jarzebski, Kalina said that steps had been taken to prevent a similar spill in the future, that both sides had agreed to the expansion of joint monitoring of border and trans-boundary rivers and that the obligation to pay for cleaning up pollution would fall on the country from which the pollution had come.

Pollution of Czechoslovak origin is a long-standing grievance to the Poles. In the mid-1970s, when Polish censorship imposed strict controls on discussion in the media of industrial degradation of the environment, the ban did not apply to pollution originating from Czechoslovakia. In the case of the recent spill, there were two main causes of tension. One was disagreement between the two sides about the extent of the spill; the other was that the Czechoslovak authorities had failed to provide the Poles with adequate and timely warning of the spill.

Although, on 9 December, the Polish government press spokesman, Mr Jerzy Urban, dismissed western reports that the spill had caused a major "conflict" betwen the two socialist states, a few days later the Warsaw correspondent of Czechoslovak television, Ratislav Baja, noted Polish complaints that the Czechoslovak authorities had provided only "incomplete" and "distorted" data. Similarly, on 19 December, the Polish Deputy Premier, Jozef Koziol, answering questions from the Parliamentary Commission on Environmental Protection, described the information provided by the Czechs as "strongly understated"

The Czechoslovak answer was that the Poles had measured the spill wrongly, as what they had collected was not oil but an oil-water mix - and that some of the pollution was probably of Polish origin anyway. There has been no attempt by the Czechs to explain the delays in information and, ironically, on the eve of the Krakow meeting, the Warsaw daily Zycie Warszawy reported yet another Czech spill near the city of Ostrava, which although not large was once again disquieting, as the Polish environmental services first learned about such events "from chance observers".

Vera Rich 